\title{
Bending Shoots Stimulates Flowering and Influences Hormone Levels in Lateral Buds of Japanese Pear
}

\author{
Akiko Ito ${ }^{1}$, Hideaki Yaegaki, Hiroko Hayama, Shinnosuke Kusaba, \\ Isomaro Yamaguchi ${ }^{2}$, and Hirohito Yoshioka ${ }^{3}$ \\ National Institute of Fruit Tree Science, Ministry of Agriculture, Forestry, and \\ Fisheries, 2-1 Fujimoto, Tsukuba, Ibaraki 305-8605, Japan
}

Additional index words. Pyrus pyrifolia, shoot elongation, auxin, abscisic acid, gibberellins, cytokinins

\begin{abstract}
Flower development of the lateral buds was accelerated in Japanese pear [Pyrus pyrifolia (Burm.) Nak.] when vertical shoots were bent at a $45^{\circ}$ angle in late June. The indole-3-acetic acid (IAA) concentration in lateral buds on vertical (control) shoots increased in mid-July, while remaining nearly constant in bent shoots. The abscisic acid (ABA) concentration of buds in bent shoots rose between 4 July and 15 Aug., whereas control shoots exhibited an increase in concentration followed by a decline. Gibberellin ${ }_{4+7}$ $\left(\mathbf{G A}_{4+7}\right)$ concentration was high on 16 June, and then declined by 4 July, with the decline being greatest in bent shoots. Gibberellin ${ }_{4+7}$ concentration was higher in the buds on vertical shoots than in those on bent shoots for much of July. The concentrations of zeatintype cytokinins (CKs) in lateral buds were higher in bent shoots than in vertical shoots. Bending of pear shoots may weaken competition between buds and other organs through altering hormone levels in lateral buds, resulting in acceleration of flower development.
\end{abstract}

Flower initiation in Japanese pear occurs in late June after shoot elongation ceases (Banno et al., 1986). Floral primordia appear in apple (Malus $\times$ domestica Borkh.) buds only when a critical number of nodes has formed on the axis (Abbott, 1970; Fulford, 1966). If the critical node number is not reached by the end of the growing season, the bud remains vegetative. This suggests that every bud can become a flower bud, but not all buds form flowers because of unsuitable conditions (Tsujikawa et al., 1990).

In Japanese pear, flower buds usually are formed on apices of spurs, and on terminal and lateral buds of shoots. The degree of flower bud formation differs among cultivars. 'Kosui', the leading cultivar in Japan, has few flower buds per shoot. Sax (1962) and Wareing (1970) reported that, in apple, bending an annual shoot increased the number of lateral flower buds. Bannoetal. (1985a) reported that 'Kosui' pear responded in a similar manner. In Japan,

Received for publication 20 Oct. 1998. Accepted for publication 26 Apr. 1999. This paper is contribution No.1141 of the National Institute of Fruit Tree Science, Ministry of Agriculture, Forestry, and Fisheries. We thank A. Kohno and H. Morimoto for technical assistance, and Dr. Kashimura for statistical advice. The cost of publishing this paper was defrayed in part by the payment of page charges. Under postal regulations, this paper therefore must be hereby marked advertisement solely to indicate this fact.

${ }^{1}$ To whom reprint requests should be addressed. Email: akiko@fruit.affrc.go.jp

${ }^{2}$ Dept. of Applied Biological Chemistry, The Univ. of Tokyo, Yayoi 1-1-1, Bunkyo-ku, Tokyo 113, Japan.

${ }^{3}$ Present address: Apple Research Center, National Institute of Fruit Tree Science, Morioka, Iwate 0200123, Japan. pear growers bend vertical shoots to a $45^{\circ}$ angle between mid-June and early July.

Plant hormones are involved in the regulation of flower bud initiation and/or development in trees (Buban and Faust, 1982; Luckwill, 1970; Lyndon, 1994; Owens, 1991). Attempts to regulate the number of flower buds in trees through the application of plant growth regulators (reviewed by Owens, 1991) have included the application of GAs (Banno et al., 1985a, 1985b; Huet, 1973; Looney et al., 1985; Luckwill, 1970), auxins (Banno et al., 1985b; Luckwill, 1970; Marcelle and Sironval, 1963), CKs (Banno et al., 1985b; McLaughlin and Greene, 1984), ABA (Banno et al., 1985b; Hoad, 1984; Rakngan et al., 1995), and ethylene (Banno et al., 1985b; Mor and Zieslin, 1987). The relationship between endogenous hormones and flower development in fruit trees remains obscure. Part of the reason is that, in most studies, the levels of endogenous hormones were determined in large organs (shoots), but not in apices due to the difficulty of collecting sufficient tissue for analysis. Gas chromatography-mass spectrometry (GC-MS) and immunologic methods have increased sensitivity; thus, small samples may be analyzed.

The objectives of this study were to quantify the seasonal changes in endogenous hormone levels in buds of Japanese pear, and to determine the effects of bending shoots on endogenous hormone levels during flower bud development.

\section{Material and Methods}

Plant material. Forty-eight 18-year-old trees of 'Kosui' pear growing in an experimental orchard at the National Institute of Fruit Tree Science (Ibaraki, Japan) were se- lected and arranged in a completely randomized design with two treatments: control trees and trees subjected to the bending treatment. Each group was subdivided into three subgroups consisting of eight trees each to allow for replication. One tree from each subgroup was used for anatomical data (determination of shoot length and bud developmental stage), and the remaining seven trees for hormonal analyses.

One hundred similarly formed, vertical shoots were tagged per tree between 20 and 27 June, avoiding the basal section of the branches. The length of the tagged shoots ranged from 55 to $90 \mathrm{~cm}$. Bent shoots were inclined at $45^{\circ}$ from the vertical and tied with strings to the trellis at a height of $180 \mathrm{~cm}$, whereas control shoots remained vertical.

Lateral buds (sample fresh weight $\approx 10 \mathrm{~g}$ ) were collected randomly on 16 June, 4 and 17 July, and 2 and 15 Aug. from the tagged shoots of each subgroup (seven trees). Immediately following collection, the samples were frozen in liquid $\mathrm{N}_{2}$ and stored at $-80{ }^{\circ} \mathrm{C}$ until analyzed. The length of 15 shoots per plot on the trees for anatomical study were measured weekly from 5 June to 17 July. Bud developmental stage was determined microscopically in buds of five uniform shoots per plot. The nine stages of flower bud development as described by Peng and Iwahori (1994) were used, viz.: $0=$ vegetative; $1=$ early stage of initiation; 2 = final stage of initiation; $3=$ lateral flower bud apparent; $4=$ bract and lateral flower buds beginning to develop; $5=$ sepal primordia developing; $6=$ petal primordia forming; $7=$ stamen primordia forming $; 8$ $=$ pistil primordia forming $; 9=$ petal and pistil well-developed. Each of the selected shoots bore between 19 and 23 lateral buds. Apical buds, and lateral buds located at the fifth node below the apex, the center node, and the fifth node from the base were also examined. The lateral buds were located near the center of the distal third, central third, and proximal third of the shoot, respectively, and will be referred to as apex, bud node 15-19, bud node 10-12, and bud node 5 , respectively. Shoots were still growing at the beginning of bud observations; thus, the stage of development of bud node 15-19 differed over time. Buds were sampled four times: on 21 June, 21 July, 21 Aug., and 18 Sept.

Hormone extraction and purification. Buds were analyzed for indole-3-acetic acid (IAA), abscisic acid (ABA), gibberellin $\left(\mathrm{GA}_{1+3}\right.$, $\left.\mathrm{GA}_{4+7}\right)$, trans-zeatin $(\mathrm{Z})$, and transzeatinriboside ([9R]Z). Hormonal analysis was performed according to Takahashi and Yamaguchi (1986) with a slight modification. Each hormone was extracted from frozen buds and fractionated with high-performance liquid chromatography (HPLC, Model LC-6AD, Shimazu Corp., Kyoto, Japan) equipped with a UV detector. Indole-3-acetic acid and ABA were estimated by gas chromatography-mass spectrometry (GC-MS), and GAs and cytokinins (CKs) by enzyme-linked immunosorbent assay (ELISA). Gibberellin ${ }_{1}$ and $\mathrm{GA}_{3}$ and $\mathrm{GA}_{4}$ and $\mathrm{GA}_{7}$ cannot be separated by the HPLC method used, so these GAs were estimated and 
evaluated as $\mathrm{GA}_{1+3}$ and $\mathrm{GA}_{4+7}$, respectively.

Each sample was divided in half; one half was used for GA, IAA, and ABA analyses and the other for CK analyses. Samples for GAs, IAA, and ABA were homogenized and extracted in $40 \mathrm{~mL}$ of $80 \%$ aqueous acetone containing butyl hydroxy toluene (BHT) at 0.1 $\mathrm{g} \cdot \mathrm{L}^{-1}$. At this point $50 \mathrm{ng}$ of $\left[{ }^{13} \mathrm{C}_{6}\right]$-IAA and 100 ng of $\left[{ }^{2} \mathrm{H}(\mathrm{D})_{3}\right]$-ABA were added as internal standards for quantification. The solution was then filtered and the residue was re-extracted twice with $40 \mathrm{~mL}$ of $80 \%$ acetone. The pooled extracts were then evaporated in vacuo to an aqueous solution, and solvent-partitioned as shown in Fig. 1 to obtain an acidic ethyl acetate-soluble (AE) fraction. Samples for $\mathrm{CK}$ analysis were similarly extracted and con-

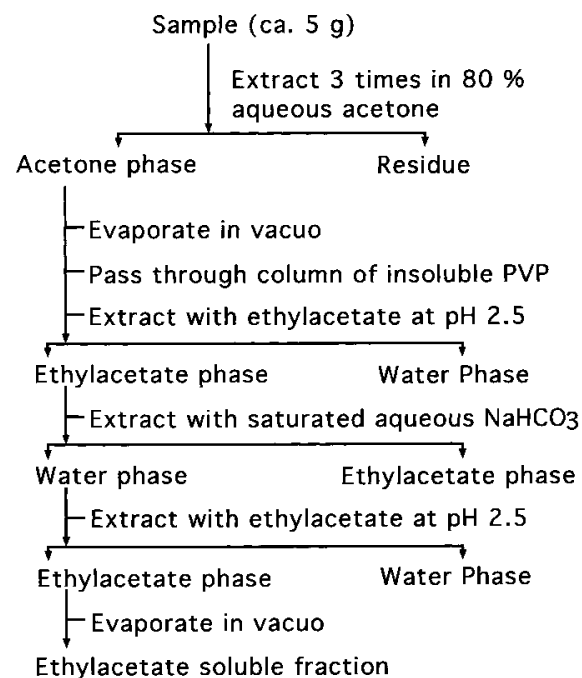

Fig. 1. Extraction and purification procedure for IAA, ABA, and GA.

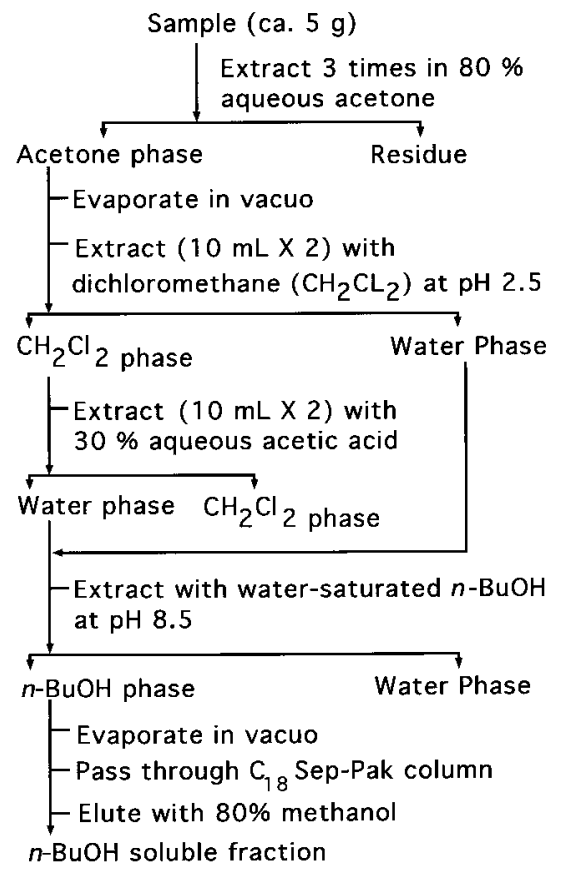

Fig. 2. Extraction and purification procedure for CK. centrated to give an aqueous solution which was subjected to solvent partitioning (Fig. 2) to obtain a fraction soluble in $n$-buthyl alcohol $(n-\mathrm{BuOH})$.

The $\mathrm{AE}$ and $n-\mathrm{BuOH}$ fractions were dried in vacuo and then dissolved separately in a small amount of methanol. Each methanol solution was loaded on a Pegasil ODS HPLC column ( $10 \mathrm{~mm}$ i.d. $\times 150 \mathrm{~mm}$; Senshu Scientific Co. Ltd., Tokyo) equilibrated with $5 \%$ acetonitrile, and eluted with a gradient of water-acetonitrile containing $0.5 \%$ acetic acid. The elution conditions were as follows: $0-5$ min 5\% acetonitrile; $5-50$ min linear gradient from $5 \%$ to $30 \%$ acetonitrile; $50-70$ min linear gradient from $30 \%$ to $80 \%$ acetonitrile; $30 \mathrm{~min}$ $80 \%$ acetonitrile wash. The flow rate during the entire elution program was $1.5 \mathrm{~mL} \cdot \mathrm{min}^{-1}$. The retention times of IAA ( $36 \mathrm{~min}), \mathrm{ABA}$ ( 47 $\mathrm{min}), \mathrm{GA}_{1+3}$ (31 $\left.\mathrm{min}\right), \mathrm{GA}_{4+7}(60 \mathrm{~min}), \mathrm{Z}$ (9 $\mathrm{min})$, and [9R]Z (20 $\mathrm{min})$ were determined by running authentic standards under the same conditions.

$G C$-MS analysis for IAA and $A B A$. Indole3-acetic acid and ABA were identified and estimated by GC-MS. Prior to the analysis, the putative $\mathrm{ABA}$ fractions were methylated with ethereal diazomethane, and the putative IAA fractions were first methylated, then trimethylsilylated with $N$-methyl- $N$ (trimethylsilyl)trifluoroacetamide. For GC-MS a JOEL (Nippon Denshi Co. Ltd., Tokyo) JMX-DX303 GC-MS equipped with a multiple ion detector was used. The column $(0.53$ $\mathrm{mm}$ i.d. $\times 15 \mathrm{~m}$ ) was packed with OV-1. Injection port, separator, and chamber temperatures were 230,250 , and $200{ }^{\circ} \mathrm{C}$, respectively. The ionization voltage was $70 \mathrm{eV}$. The temperature program was as follows: $0-1 \mathrm{~min}$ at $120^{\circ} \mathrm{C} ; 1-11 \mathrm{~min}$ linear gradient from 120 $280{ }^{\circ} \mathrm{C}$, followed by $10 \mathrm{~min}$ at $280{ }^{\circ} \mathrm{C}$. Selected ion monitoring was conducted at $\mathrm{m} / \mathrm{e}$ $202 / 208$ and $261 / 267$ for IAA/ $\left[{ }^{13} \mathrm{C}_{6}\right]$-IAA, and $134 / 137,162 / 165$, and $190 / 193$ for $\mathrm{ABA} /\left[\mathrm{D}_{3}\right]$ $\mathrm{ABA}$, respectively. The relative intensities of the ions $m / e$ 202/208 and 190/193 were traced to identify IAA and ABA, respectively. Hormones were quantified from a standard curve using authentic IAA and ABA.
Identification and semi-quantification of $G A$ and $C K$. GA and CK were identified and estimated based on their retention times on HPLC and immuno-reactivities to specific antibodies.

The $\mathrm{GA}_{1+3}$ fractions were analyzed with polyclonal antibodies raised against $\mathrm{GA}_{1}$-bovine serum albumin (BSA) conjugate via the C-7 carboxyl group of the GA, as reported by Atzorn and Weiler (1983), and the $\mathrm{GA}_{4+7}$ fractions were analyzed with monoclonal antibodies against $\mathrm{GA}_{4}$ prepared by Nakajima et al. (1991). The cross-reactivities of the antibodies raised against $\mathrm{GA}_{1}$ to $\mathrm{GA}_{3}$, and against $\mathrm{GA}_{4}$ to $\mathrm{GA}_{7}$ were $70 \%$ and $72 \%$, respectively, on a molar basis. The ELISA assay was performed as described by Atzorn and Weiler (1983) for $\mathrm{GA}_{1+3}$, and by Nakajima et al. (1991) for $\mathrm{GA}_{4+7}$.

Zeatin and $[9 \mathrm{R}] \mathrm{Z}$ were analyzed by ELISA with polyclonal antibody against [9R]Z, which is highly specific for Z and [9R]Z, as described by Weiler (1980). Synthesis of [9R]Z-immunogens is reported in Weiler and Spanier (1981). The quantified values were evaluated as $\mathrm{Z}$-equivalent for $\mathrm{Z}$ and [9R]Z. The crossreactivity of antibody raised against $[9 \mathrm{R}] \mathrm{Z}$ to $\mathrm{Z}$ was $44 \%$, on a molar basis.

Statistical procedures. Data on stage of flower development were analyzed using the analysis of variance (ANOVA) procedure, and means were separated with Duncan's new multiple range test. Data for hormone concentrations were compared using Tukey's honestly significant difference.

\section{Results}

Shoot length. Shoots elongated until early July (Fig. 3). The bending treatment was initiated when shoot elongation had almost ceased; thus, the elongation rates and final lengths of the vertical vs. the bent shoots were not significantly different.

Flower development. Since in no case was the interaction of treatment and position significant by ANOVA, only main-effect means are presented (Table 1). In both treatments, flower development in the apical buds occurred earlier than in the lateral buds. Variabil-

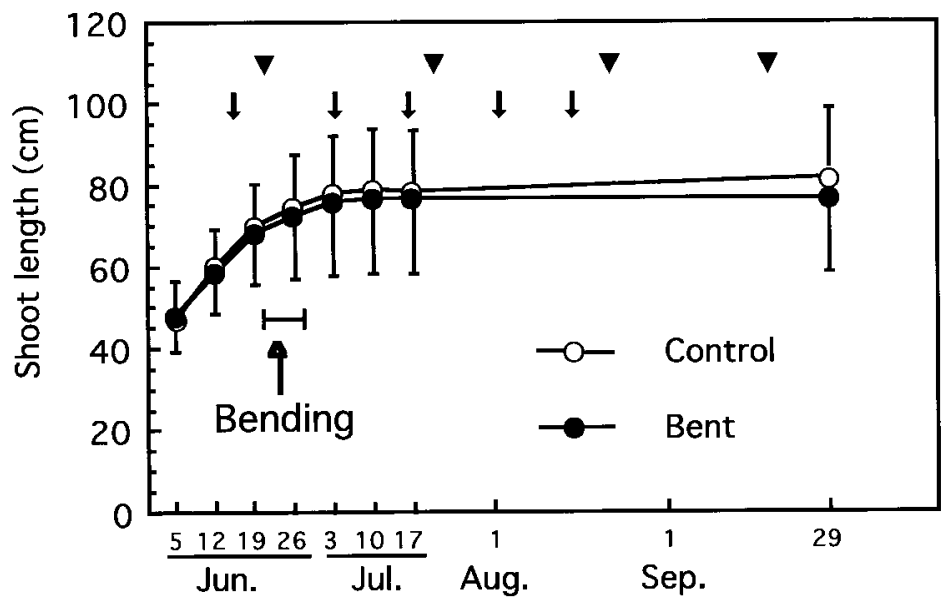

Fig. 3. Effects of bending on shoot elongation in 'Kosui' Japanese pear. Shoots were bent during the period from 20 to 27 June. Vertical bars indicate SE for 15 shoots. The symbols $\downarrow$ and $\boldsymbol{\nabla}$ indicate the dates of bud sampling and observation of bud development, respectively. 
ity was large within each plot, so the effect of bending shoots on flower development was nonsignificant on most dates except for 18 Sept., when bending treatment significantly accelerated flower development regardless of bud position.

Hormonal changes. Indole-3-acetic acid concentration in lateral buds of control shoots rose in early- to mid-July, before declining in mid-August (i.e., the concentration rose after shoot elongation ceased) (Fig. 4A). In contrast, the IAA concentration in lateral buds on bent shoots remained relatively constant throughout the measurement period.

Abscisic acid concentration in both treatments increased until early July, then declined in the control (Fig. 4B). However, it continued to increase in buds on bent shoots and was significantly higher than in the controls on 15 Aug.

The concentration of $\mathrm{GA}_{4+7}$ was high initially, then declined in both treatments (Fig. 5A) as shoot elongation ceased (Fig. 3). The decline was greater in bent than in control shoots. Concentrations of $\mathrm{GA}_{1+3}$ were much lower than those of $\mathrm{GA}_{4+7}$ in both treatments, and changed less throughout the measurement period (Fig. 5B)

The concentration of $\mathrm{Z}$ declined throughout the period of measurement in control shoots (Fig. 6A), but bending increased the concentration, which was significantly higher than that of the control on 4 and 17 July and 2 Aug. Bending had a similar effect on [9R]Z concentration, and was higher in the bent than in the vertical shoots on 17 July and 2 Aug. (Fig. 6B).

\section{Discussion}

Japanese pear growers bend vertical shoots in late June when shoot elongation has almost ceased (Fig. 3). The treatment accelerates lateral flower development regardless of the bud position (Table 1). Tromp (1967) discovered that horizontally grown apple trees form more flower buds and terminate growth sooner than do vertical trees. Other researchers (Luckwill, 1970; Owens, 1991) reported a similar relationship between number of flowers and cessation of shoot elongation. In our experiment, however, bending accelerated bud development without affecting shoot elongation, probably because the treatment was applied near the end of the shoot elongation period. A similar observation was made by Tromp (1972).

Bud development was more rapid on bent than on control shoots regardless of bud position. The buds for hormonal analysis were sampled regardless of position. Therefore, the results are meaningful only for the general (regardless of bud position) comparison of hormones and flowering. Another experiment must be conducted to establish a specific relationship between hormones and flowering at specific positions.

Previous studies involving applications of plant growth regulators or estimations of endogenous hormonal levels have shown relationships between flower development and levels of plant hormones, although there are

Table 1. Effects of bending and position on seasonal change in developmental stage in buds of 'Kosui' Japanese pear. $^{2}$

\begin{tabular}{llcccc}
\hline \hline & & \multicolumn{3}{c}{ Date } \\
\cline { 3 - 6 } Main effect & & 21 June & 21 July & 21 Aug. & 18 Sept. \\
\hline Treatments (T) & Control & 0.0 & 0.7 & 2.0 & 1.9 \\
& Bent & 0.0 & 1.0 & 2.2 & 3.6 \\
Position (P) $)^{\mathrm{y}, \mathrm{x}}$ & Apex & 0.0 & $1.9 \mathrm{a}$ & $4.2 \mathrm{a}$ & $4.0 \mathrm{a}$ \\
& Node 14-18 & 0.0 & $0.5 \mathrm{~b}$ & $2.0 \mathrm{~b}$ & $3.5 \mathrm{a}$ \\
& Node 10-12 & 0.0 & $0.4 \mathrm{~b}$ & $1.5 \mathrm{bc}$ & $3.0 \mathrm{a}$ \\
& Node 5 & 0.0 & $0.4 \mathrm{~b}$ & $0.7 \mathrm{c}$ & $0.9 \mathrm{~b}$ \\
Analysis of variance & & & & & \\
Treatments (T) & & NS & NS & NS & $*$ \\
Position (P) & & NS & $* *$ & $* *$ & $* *$ \\
T $\times$ P & NS & NS & NS & NS
\end{tabular}

${ }^{2}$ Nine stages of flower bud development are as follows (Peng and Iwahori, 1994): $0=$ vegetative; $1=$ early stage of initiation; 2 = final stage of initiation; $3=$ lateral flower bud apparent; $4=$ bract and lateral flower buds beginning to develop; $5=$ sepal primordia developing; $6=$ petal primordia forming; $7=$ stamen primordia forming; $8=$ pistil primordia forming; $9=$ petal and pistil well developed.

'Buds observed were; apex, bud node 14-18 (fifth node below the apex), bud node 10-12 (center node), and bud node 5 (fifth node from the basal end).

'Mean separation within columns and positions by Duncan's new multiple range test $(P \leq 0.05)$.

Ns, ${ }^{*}, * *$ Nonsignificant or significant at $P \leq 0.05$ or 0.01 , respectively.

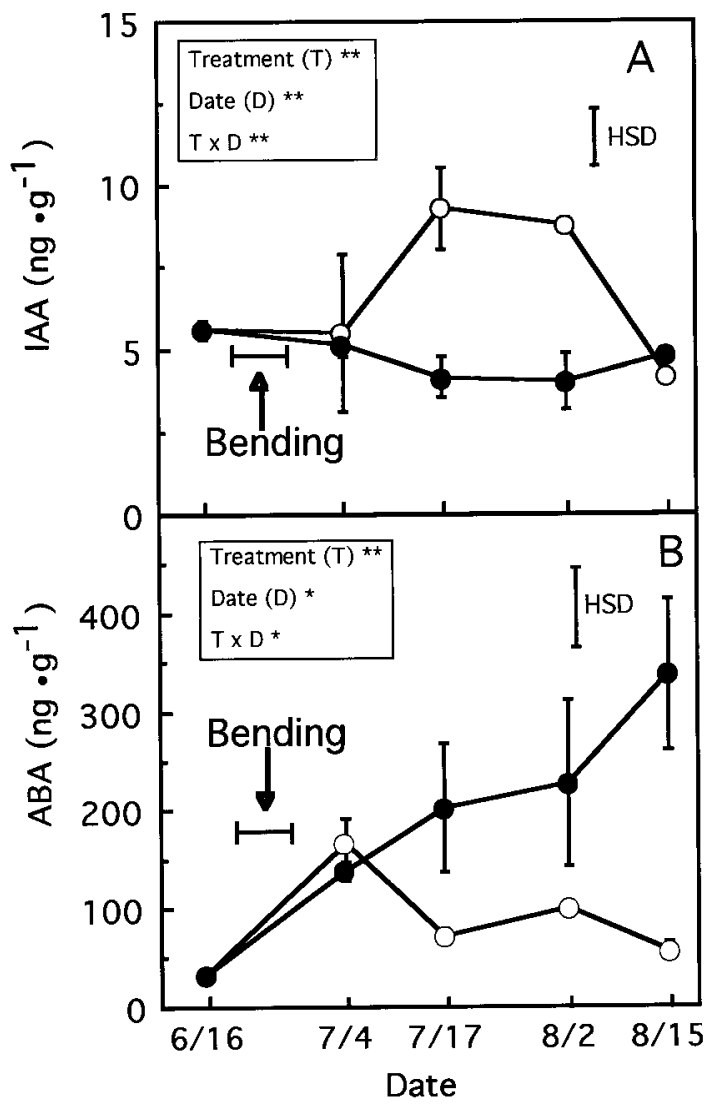

Fig. 4. Seasonal change in (A) IAA and (B) ABA concentrations (ng. $\mathrm{g}^{-1}$ fresh weight) in lateral buds of control $(O)$ and bent $(\bullet)$ shoots of 'Kosui' Japanese pear. Values are means \pm SE, $\mathrm{n}=3$ (SE bars present only when larger than symbol). Vertical bar indicates Tukey's honestly significant difference $(P \leq 0.05)$. ss, ****Nonsignificant or significant at $P \leq 0.05$ or 0.01 , respectively, by analysis of variance.

many conflicting or uncertain results (reviewed by Buban and Faust, 1982; Hoad, 1984; Owens, 1991). The effect of auxin on flowering is unclear (Buban and Faust, 1982; Jackson and Sweet, 1972), since it has increased flowering in some studies (Southwick and Weeks, 1950), but not others (Luckwill, 1970). On the contrary, inhibitors of auxin efflux reportedly stimulate flowering (Edgerton and Hoffman, 1965; Luckwill, 1970; Owens, 1991).
Gibberellins inhibit flowering of apple and pear (Banno et al., 1985b; Griggs et al., 1970; Higashiuchi et al., 1990; Hoad, 1978; Huet, 1973; Owens, 1991). Auxin and GAs may affect flowering by increasing the sink strength of apical buds (i.e., vegetative shoot elongation) (Cline, 1994; Ho, 1994; Sachs, 1977, 1993). However, Looney et al. (1985) reported that $\mathrm{GA}_{4}$ may increase flowering in apple. These conflicting reports may indicate 


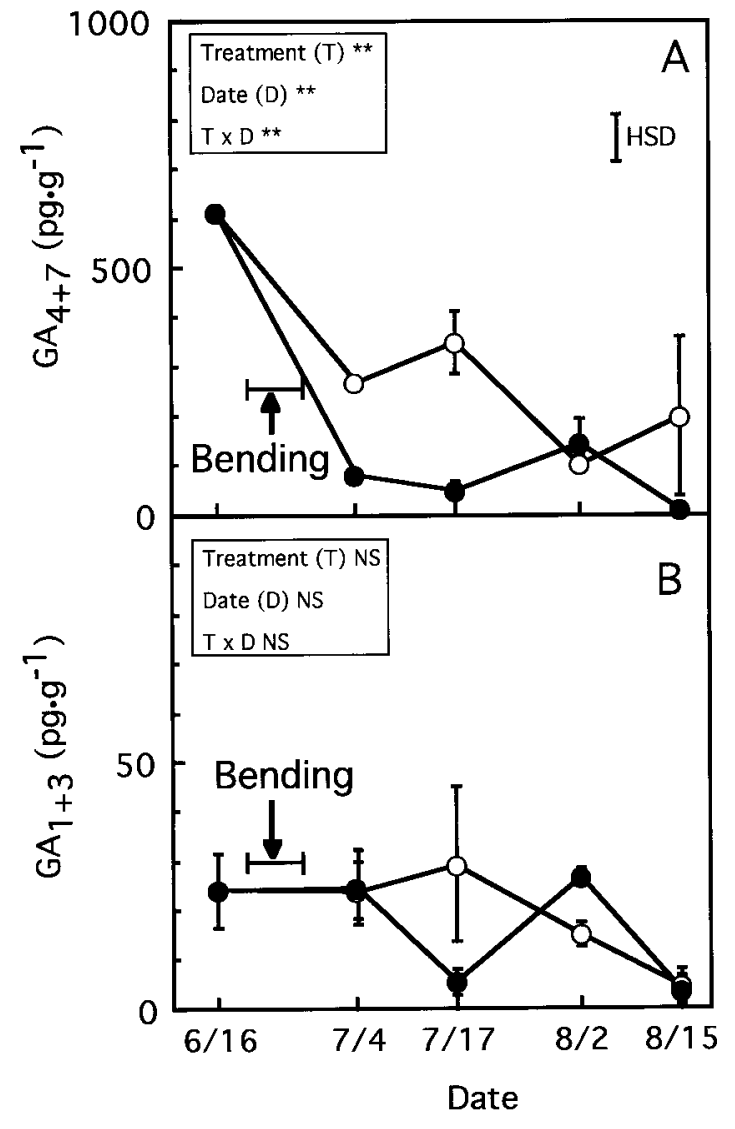

Fig. 5. Seasonal change in $(\mathbf{A}) \mathrm{GA}_{4+7}$ and (B) $\mathrm{GA}_{1+3}$ concentrations (pg. $\mathrm{g}^{-1}$ fresh weight) in lateral buds of control $(O)$ and bent $(\mathbf{)}$ shoots of 'Kosui' Japanese pear. Values are means $\pm \mathrm{SE}, \mathrm{n}=3$ (SE bars present only when larger than symbol). Vertical bar indicates Tukey's honestly significant difference $(P \leq 0.05)$. ${ }^{\mathrm{Ns}, *, * *}$ Nonsignificant or significant at $P \leq 0.05$ or 0.01 , respectively, by analysis of variance. Note that the vertical scales differ for $\mathrm{A}$ and $\mathrm{B}$.

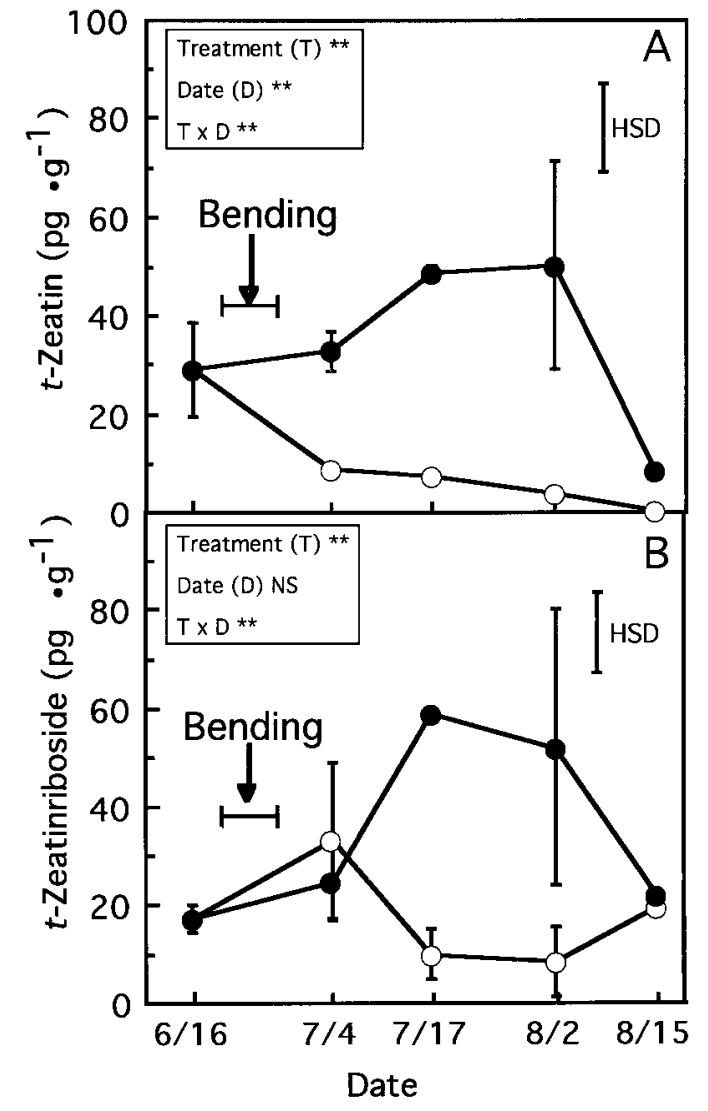

Fig. 6. Seasonal changes in (A) trans-zeatin, and (B) trans-zeatinriboside concentrations ( $\mathrm{pg} \cdot \mathrm{g}^{-1}$ fresh weight) in lateral buds of control $(\bigcirc)$ and bent (-) shoots of 'Kosui' Japanese pear. Values are means \pm SE, $n=3$ (sE bars present only when larger than symbol). Vertical bar indicates Tukey's

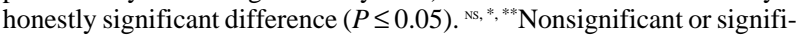
cant at $P \leq 0.05$ or 0.01 , respectively, by analysis of variance. that GAs influence flowering without affecting growth, or that the response of the meristem to GA may vary depending on the developmental stage (Bonnet-Masimbert and Zaerr, 1984).

In contrast, $\mathrm{CK}$ are reported to increase flower bud development in some fruit species (Banno et al., 1985b; Luckwill, 1970; McLaughlin and Greene, 1984; Ramirez and Hoad, 1981), probably by activating cell division within the buds (McGaw, 1995; McLaughlin and Greene, 1991).

The direct role of ABA in flower bud development is thought to be negligible (Hoad, 1984), yet promotive effects of ABA on flower bud development have been reported (Rakngan et al., 1995). Abscisic acid may increase the concentration of sugars in the vacuole, resulting in increased sink strength (Kojima et al., 1995; Kondo and Gemma, 1993).

Bending shoots decreased IAA (Fig. 4A) and $\mathrm{GA}_{4+7}$ (Fig. 5A) concentrations in lateral buds, but increased ABA (Fig. 4B) and CK (Fig. 6). These hormonal changes should enhance flower development. However, our study does not clearly identify which hormone(s) are responsible for the effects of shoot bending on flower development. Additionally, others have shown that shoot bending increases ethylene production in apple shoots (Leopold et al., 1972; Robitaille and Leopold, 1974; Sanyal and Bangerth, 1998). Ethylene application can increase flowering in rose (Mor and Zieslin, 1987), pear (Banno et al., 1985b), and apple (Buban and Faust, 1982); thus, the effect of bending Japanese pear shoots on ethylene production merits re-examination.

While shoot bending influenced hormone levels, certain of these changes may have been the result of changes in other hormone(s) or alterations in the physical characteristics of the shoot. For example, shoot bending reduces the basipetal transport of IAA (Bangerth, 1990, 1993), and this could reduce IAA content of lateral buds. Van Huizen et al. (1995) reported that auxins stimulate the conversion of GA from inactive to active forms in peas (Pisum sativum L.). Therefore, the decrease in GA observed in this experiment may have been a result of reduced IAA levels. A decrease in the auxin concentration following decapitation can increase the cytokinin concentration either by increasing transport in the xylem (in bean; Bangerth, 1994), or by increasing metabolism in the buds (in pea; King and van Staden, 1987). So, CK levels also may be tied to auxin levels. Additionally, the relation between ethylene production and auxin level is also suggested in apple; ethylene reduces polar auxin transport (Sanyal and Bangerth, 1998), whereas auxin application increases the ethylene level (Robilaille and Leopold, 1974).

Tsujikawa et al. (1990) reported that the removal of competing sinks, such as young leaves or fruits, promoted flowering of Japanese pear. Sink strength and/or dominance strongly correlates with cytokinin concentration in the organs and with the auxin transport rate of each organ (Bangerth, 1993; Ho, 1994; Sachs, 1993). Thus, the relationship between auxin transport and flower development after shoot bending merits re-examination.

In conclusion, shoot bending advanced flower development. This advancement was associated with notable changes in hormone levels. We propose that the bending of pear shoots alters hormone levels, thereby increasing the ability of the lateral buds to compete for assimilates.

\section{Literature Cited}

Abbott, D.L. 1970. The role of budscales in the morphogenesis and dormancy of the apple fruit bud, p. 65-80. In: L.C. Luckwill and C.V. Cutting (eds.). Physiology of tree crops. Academic Press, London.

Atzorn, R. and E.W. Weiler. 1983. The immunoassay of gibberellins. II. Quantitation of $\mathrm{GA}_{3}$, $\mathrm{GA}_{4}$, and $\mathrm{GA}_{7}$ by ultra-sensitive solid-phase enzyme immunoassays. Planta 159:7-11. 
Bangerth,F. 1990. Polar auxin transport in fruit trees in relation to fruit drop. Acta Hort. 275:461-468.

Bangerth, F. 1993. Polar auxin transport as a signal in the regulation of tree and fruit development. Acta Hort. 329:70-76.

Bangerth, F. 1994. Response of cytokinin concentration in the xylem exudate of bean (Phaseolus vulgaris $\mathrm{L}$.) plants to decapitation and auxin treatment, and relationship to apical dominance. Planta 194:439-442.

Banno, K., S. Hayashi, and K. Tanabe. 1985a. Effects of SADH and shoot-bending on flower bud formation, nutrient components and endogenous growth regulators in Japanese pear (Pyrus serotina Rehd.). J. Jpn. Soc. Hort. Sci. 53:365376. (in Japanese with English abstract and figures).

Banno, K., S. Hayashi, and K. Tanabe. 1985b. Effect of application of growth regulators on flower bud formation in Japanese pear (Pyrus serotina Rehd.). Fac. Agr., Tottori Univ. Bul. 38:11-15. (in Japanese).

Banno, K., S. Hayashi, and K. Tanabe. 1986. Morphological and histological studies on flower bud differentiation and development in Japanese pear (Pyrus serotina Rehd.). J. Jpn. Soc. Hort. Sci. 55:258-265.

Bonnet-Masimbert, M. and J.B. Zaerr. 1987. The role of plant growth regulators in promotion of flowering. Plant Growth Regulat. 6:13-35.

Buban, T. and M. Faust. 1982. Flower bud induction in apple trees: Internal control and differentiation. Hort. Rev. 4:174-203.

Cline, M.G. 1994. The role of hormones in apical dominance. New approaches to an old problem in plant development. Physiol. Plant. 90:230 237.

Edgerton, L.J. and M.B. Hoffman. 1965. Some physiological responses of apple to $N$-dimethyl amino succinamic acid and other growth regulators. Proc. Amer. Soc. Hort. Sci. 86:28-36.

Fulford, R.M. 1966. The morphogenesis of apple buds. III. The inception of flowers. Ann. Bot. 30:207-219.

Griggs, W.H., G.C. Martin, and B.T. Iwakiri. 1970 The effect of seedless versus seeded fruit development on flower bud formation in pear. J. Amer. Soc. Hort. Sci. 95:243-248.

Higashiuchi, Y., K. Kido, T. Ichii, T. Nakanishi, Y. Kawai, and T. Ozaki. 1990. The effect of gibberellins and growth retardants on in vitro flowering of the vegetative apex of Japanese pear. Scientia Hort. 41:223-232.

Ho, L.C. 1994. Fruit growth and sink strength, p. 101-124. In: C. Marshall and J. Grace (eds.). Fruit and seed production. Aspects of development, environmental physiology and ecology. Cambridge Univ. Press, U.K.

Hoad, G.V. 1978. The role of seed derived hormones in the control of flowering in apple. Acta Hort. 80:93-103.

Hoad, G.V. 1984. Hormonal regulation of fruit-bud formation in fruit trees. Acta Hort. 149:13-23.

Huet, J. 1973. Floral initiation in pear trees. Acta Hort. 34:193-198.

Jackson, D.I. and G.B. Sweet. 1972. Flower initiation in temperate woody plants. Hort. Abstr. 42:9-24.

King, R.A. and J. van Staden. 1987. The metabolism of $\mathrm{N}^{6}-\left(\Delta^{2}\right.$-isopentenyl $)\left[{ }^{3} \mathrm{H}\right]$ adenine by isolated organs of Pisum sativum. J. Plant Physiol. 131: 181-190.

Kojima, K., Y. Yamada, and M. Yamamoto. 1995. Effects of abscisic acid injection on sugar and organic acid contents of citrus fruit. J. Jpn. Soc. Hort. Sci. 64:17-21.

Kondo, S. and H. Gemma. 1993. Relationship between abscisic acid (ABA) content and maturation of the sweet cherry. J. Jpn. Soc. Hort. Sci. 62:63-38.

Leopold, A.C., K.M. Brown, and F.H. Emerson 1972. Ethylene in the wood of stress trees. HortScience 7:175.

Looney, N.E., R.P. Pharis, and M. Noma. 1985. Promotion of flowering in apple trees with gibberellin $\mathrm{A}_{4}$ and $\mathrm{C}-3$ epi-gibberellin $\mathrm{A}_{4}$. Planta 165:292-294.

Luckwill, L.C. 1970. The control of growth and fruitfulness of apple trees, p. 237-254. In: L.C. Luckwill and C.V. Cutting (eds.). Physiology of tree crops. Academic Press, London.

Lyndon, R.F. 1994. The environmental control of reproductive development, p. 9-32. In: C. Marshall and J. Grace (eds.). Fruit and seed production. Aspects of development, environmental physiology and ecology. Cambridge Univ. Press, U.K.

Marcelle, R. and C. Sironval. 1963. Effect of gibberellic acid on flowering of apple trees. Nature 197:405.

McGaw, B.A. 1995. Hormonal regulation of apical dominance, p. 98-117. In: P.J. Davies (ed.) Plant hormones. Kluwer Academic, Dordrecht.

McLaughlin, J.M. and D.W. Greene. 1984. Effects of BA, $\mathrm{GA}_{4+7}$, and daminozide on fruit set, fruit quality, vegetative growth, flower initiation, and flower quality of 'Golden Delicious' apple. J. Amer. Soc. Hort. Sci. 109:34-39.

McLaughlin, J.M. and D.W. Greene. 1991. Fruit and hormones influence flowering of apple. II. Effects of hormones. J. Amer. Soc. Hort. Sci. 116:450-453.

Mor, Y. and N. Zieslin. 1987. Plant growth regulators in rose plants. Hort. Rev. 9:53-73.

Nakajima, M. I. Yamaguchi, A. Nagatani, S. Kizawa, N. Murofushi, M. Furuya, and N. Takahashi. 1991. Monoclonal antibodies specific for nonderivatized gibberellins 1.Preparation of monoclonal antibodies against $\mathrm{GA}_{4}$ and their use in mmunoaffinity column chromatography. Plant Cell Physiol. 32:515-521.

Owens, J.N. 1991. Flowering and seed set, p. 247 271. In: A.S. Raghavendra (ed.). Physiology of trees. Wiley, New York.
Peng, S.-A. and S. Iwahori. 1994. Morphological and cytological changes in apical meristem during flower bud differentiation of Japanese pear, Pyrus pyrifolia Nakai. J. Japan. Soc. Hort. Sci. 63:313-321. (in Japanese with English abstract and figures.)

Rakngan, J., H. Gemma, and S. Iwahori. 1995 Flower bud formation in Japanese pear trees under adverse conditions and effects of some growth regulators. Jpn. J. Trop. Agr. 39:1-6.

Ramirez, H. and G.V. Hoad. 1981. Effects of growth substances on fruit bud initiation in apple. Acta Hort. 120:131-136.

Robitaille,H.A. and C. Leopold. 1974. Ethylene and the regulation of apple stem growth under stress. Physiol. Plant. 32:301-304.

Sachs, R.M. 1977. Nutrient diversion: An hypothesis to explain the chemical control of flowering. HortScience 12:220-222.

Sachs, T. 1993. The role of auxin in plant organization. Acta Hort. 329:162-168.

Sanyal, D. and F. Bangerth, 1998. Stress induced ethylene evolution and its possible relationship to auxin-transport, cytokinin levels, and flower bud induction in shoots of apple seedlings and bearing apple trees. Plant Growth Regulat. 24:127-134

Sax, K. 1962. Aspects of ageing in plants. Annu. Rev. Plant Physiol. 13:489-506.

Southwick, F.W. and W.D. Weeks. 1950. Some attempts to thin apples with naphthaleneacetic acid type materials after calyx. Proc. Amer. Soc. Hort. Sci. 56:70-75.

Takahashi, N. and I. Yamaguchi. 1986. Analyses of endogenous plant hormone levels throughout the life cycle of higher plants. Acta Hort. 176:4757.

Tromp, J. 1967. Fruit-bud formation and shoot growth in apple in relation to gravity. Narurwissenshaften 54:95.

Tromp, J. 1972. Effects of growth-regulating substances and tree orientation on growth and flowerbud formation in apple. J. Hort. Sci. 47:525533.

Tsujikawa, T., T. Ichii, T. Nakanishi, T. Ozaki, and Y. Kawai. 1990. In vitro flowering of Japanese pear and the effect of $\mathrm{GA}_{4+7}$. Scientia Hort 41:233-245

Van Huizen, R., J.A. Ozga, D.M. Reinecke, B Twitchin, and L.N. Mander. 1995. Seed and 4 chloroindole-3-acetic acid regulation of gibberellin metabolism in pea pericarp. Plant Physiol. 109:1213-1217.

Wareing, P. 1970. Growth and its co-ordination in trees, p. 1-21. In: L.C. Luckwill and C.V. Cutting (eds.). Physiology of tree crops. Academic Press, London.

Weiler, E.W. 1980. Radioimmunoassays for transzeatin and related cytokinins. Planta 149:155-162.

Weiler, E.W. and K. Spanier. 1981. Phytohormones in the formation of crown gall tumors. Planta $153: 326-337$ 